\title{
Enhanced Efficiency in Dye-Sensitized Solar Cells by Electron Transport and Light Scattering on Freestanding $\mathrm{TiO}_{2}$ Nanotube Arrays
}

\author{
Won-Yeop Rho ${ }^{1}$, Da Hyun Song ${ }^{2}$, Sang Hun Lee ${ }^{1}$ and Bong-Hyun Jun ${ }^{1, *}$ \\ 1 Department of Bioscience and Biotechnology, Konkuk University, Seoul 143-701, Korea; \\ rho7272@gmail.com (W.-Y.R.); shlee.ucb@gmail.com (S.H.L.) \\ 2 Department of Chemistry, Seoul National University, Seoul 151-747, Korea; songssi87@snu.ac.kr \\ * Correspondence: bjun@konkuk.ac.kr; Tel.: +82-2-450-0521
}

Received: 14 September 2017; Accepted: 19 October 2017; Published: 24 October 2017

\begin{abstract}
Dye-sensitized solar cells (DSSCs) were fabricated with closed- or open-ended freestanding $\mathrm{TiO}_{2}$ nanotube arrays as photoelectrodes that were decorated with carbon materials and large $\mathrm{TiO}_{2}$ nanoparticles (NPs) to enhance energy conversion efficiency. The energy conversion efficiency of DSSCs based on open-ended freestanding $\mathrm{TiO}_{2}$ nanotube arrays increased from $4.47 \%$ to $5.39 \%$, compared to the DSSCs based on closed-ended freestanding $\mathrm{TiO}_{2}$ nanotube arrays. In DSSCs based on the open-ended freestanding $\mathrm{TiO}_{2}$ nanotube arrays, the energy conversion efficiency with carbon materials increased from $5.39 \%$ to $6.19 \%$ due to better electron transport, and that with a scattering layer from $5.39 \%$ to $6.24 \%$ due to more light harvesting compared to the DSSCs without carbon materials or scattering layer. Moreover, the energy conversion efficiency of DSSCs based on the open-ended freestanding $\mathrm{TiO}_{2}$ nanotube arrays with both carbon materials and scattering layer increased from $5.39 \%$ to $6.98 \%$, which is an enhancement of $29.50 \%$. In DSSCs based on the $\mathrm{TiO}_{2}$ nanotube arrays, the carbon materials can improve electron transport by $\pi-\pi$ conjugation, and the large $\mathrm{TiO}_{2} \mathrm{NPs}$ can enhance the capacity to light-harvest by scattering.
\end{abstract}

Keywords: dye-sensitized solar cell; $\mathrm{TiO}_{2}$ nanotube arrays; carbon materials; scattering layer

\section{Introduction}

Building-integrated photovoltaics (BIPVs) are one of the essential components in the Smart Grid, and require transparency, flexibility, light weight, low cost, and high power conversion efficiency [1,2]. Since their initial development in 1991 by the Grätzel group [3,4], dye-sensitized solar cells (DSSCs) have been one of the promising BIPV candidates, since their structure is composed of transparent conducting oxide (TCO), an $n$-type nanostructured semiconductor, a visible-light absorber sensitizer, electrolytes (iodide/triiodide, $\mathrm{I}^{-} / \mathrm{I}_{3}{ }^{-}$), and a counter electrode [5]. In addition, eco-friendliness and improvement in stability have become one of the foci in recent research into DSSCs. Liquid-state electrolytes consisting of redox couple and a few additives have been used in conventional DSSCs because of their high energy conversion efficiency [3]. However, to improve the stability of the DSSCs, quasi-solid or solid-state electrolytes would be more favored over the liquid-state electrolytes. For the development of eco-friendly devices, water-based DSSCs (i.e., "aqueous DSSCs") have attracted attention as they exhibit non-flammable, cost-effective, and eco-friendly properties [1,2,5-9].

Mesoporous $\mathrm{TiO}_{2}$ nanoparticle (NP) films are generally used in the studies of DSSCs, as the films have a desirable direct band gap $(3.2 \mathrm{eV})$ and a large surface area for adsorbing dyes, both of which help to generate electrons [10-13]. However, the efficiencies of the films might be limited by their grain boundaries, defects, and innumerous trapping sites that can cause charge recombination and low electron mobility from their structures, which are randomly networked $[4,14]$. 
$\mathrm{TiO}_{2}$ nanotubes have great potential to overcome the issues of $\mathrm{TiO}_{2} \mathrm{NP}$ films, since their unique structure enhances electron transport and charge separation by forging direct pathways and by accelerating charge transfer between interfaces [15-17]. $\mathrm{TiO}_{2}$ nanotube arrays can improve energy conversion efficiencies because of their highly-ordered and vertically-oriented tubular structures and because of their innate advantages. The structure of $\mathrm{TiO}_{2}$ nanotube arrays needs to be taken into consideration in order to capitalize on the advantages of $\mathrm{TiO}_{2}$ nanotube arrays. Although DSSCs based on $\mathrm{TiO}_{2}$ nanotube arrays have a great potential for enhancing power conversion efficiency (PCE), DSSCs based on closed-ended $\mathrm{TiO}_{2}$ nanotube arrays-which are the typically employed $\mathrm{TiO}_{2}$ nanotube arrays-exhibited lower energy conversion efficiencies than those of DSSCs based on $\mathrm{TiO}_{2} \mathrm{NP}$ films. Recently, we have demonstrated that open-ended $\mathrm{TiO}_{2}$ nanotube arrays in DSSCs, where barrier layers have been removed, exhibited higher PCE [18].

Scattering materials such as $\mathrm{TiO}_{2}, \mathrm{ZrO}_{2}$, and $\mathrm{SiO}_{2}$ can improve the energy conversion efficiency by light harvesting. Especially, $\mathrm{TiO}_{2}$ is one of the best materials to use for scattering owing to its high chemical stability and dye adsorption capability. As such, $\mathrm{TiO}_{2}$ scattering materials have been introduced on mesoporous $\mathrm{TiO}_{2} \mathrm{NP}$ films for the enhancement of light harvesting [19].

Carbon materials, including carbon nanotubes (CNTs), graphene, or graphite, are promising materials in improving charge separation and electron transport in solar cells due to their enhanced electrical properties by $\pi-\pi$ conjugation. The main role of carbon 60 or CNTs in organic solar cells is to function as electron acceptors or charge separators [20]. $\mathrm{TiO}_{2}$ composite films with carbon nanotubes or graphene as photoanodes showed better energy conversion efficiency due to the $\mathrm{sp}^{2}$ structure of the carbon materials [21-24]. However, it remains a challenging task to directly incorporate those carbon materials into a well-ordered and vertically oriented tubular structure of $\mathrm{TiO}_{2}$ nanotube arrays.

Herein, we show that large $\mathrm{TiO}_{2} \mathrm{NPs}$ were introduced onto open- or closed-ended freestanding $\mathrm{TiO}_{2}$ nanotube arrays for more light harvesting, and subsequently carbon materials were synthesized into the well-ordered and vertically oriented tubular structure of $\mathrm{TiO}_{2}$ nanotube arrays for better electron transport. The performances of DSSCs based on the open- or closed-ended freestanding $\mathrm{TiO}_{2}$ nanotube arrays with/without carbon materials and/or large $\mathrm{TiO}_{2} \mathrm{NPs}$ were compared to elucidate the influence of each component on the energy conversion efficiency of DSSCs.

\section{Results and Discussion}

Figure 1 illustrates the fabrication of DSSCs based on closed- or open-ended freestanding $\mathrm{TiO}_{2}$ nanotube arrays with carbon materials and large $\mathrm{TiO}_{2} \mathrm{NPs}$ as photoanode. The closed- or open-ended freestanding $\mathrm{TiO}_{2}$ nanotube arrays were prepared by anodization, and their bottom layer was removed by ion milling process. When the bottom layer is present under the freestanding $\mathrm{TiO}_{2}$ nanotube arrays, they are known as "closed-ended" freestanding $\mathrm{TiO}_{2}$ nanotube arrays, whereas without the bottom layer, they are called "open-ended" freestanding $\mathrm{TiO}_{2}$ nanotube arrays. Both types of freestanding $\mathrm{TiO}_{2}$ nanotube arrays were attached on the fluorine-doped tin oxide (FTO) glass, and the large $\mathrm{TiO}_{2} \mathrm{NPs}$ $(\sim 400 \mathrm{~nm})$ were coated onto both types of freestanding $\mathrm{TiO}_{2}$ nanotube arrays as shown in Figure 1a. The carbon materials were synthesized by the chemical vapor deposition (CVD) method (Figure 1b), and then the dye (N719) was adsorbed onto both types of freestanding $\mathrm{TiO}_{2}$ nanotube array (Figure 1c). Finally, DSSCs were fabricated by assembling the photoanode and counter electrode that were coated with platinum $(\mathrm{Pt})$ on the FTO glass. Electrolyte was injected between the photoanode and counter electrode (Figure 1d).

Figure 2 shows field emission scanning electron microscope (FE-SEM) images of closed- or open-ended freestanding $\mathrm{TiO}_{2}$ nanotube arrays. The top view of the freestanding $\mathrm{TiO}_{2}$ nanotube arrays can been seen in Figure 2a. The pore size was approximately $100 \mathrm{~nm}$ after anodization. Figure $2 \mathrm{~b}$ shows the bottom view of freestanding $\mathrm{TiO}_{2}$ nanotube arrays before the ion milling process. The pattern of the bottom pore size was about $100 \mathrm{~nm}$. Figure 2c shows the bottom view of freestanding $\mathrm{TiO}_{2}$ nanotube arrays after the ion milling process, and the pore size was about $30 \mathrm{~nm}$. The size of the bottom pore was much smaller when compared to the sizes of top pore and the pattern of the bottom 
pore. However, when the levels of thickness were compared, the bottom wall ( $35 \mathrm{~nm})$ was much thicker than the top wall of the freestanding $\mathrm{TiO}_{2}$ nanotube arrays. In previous works [18,25-30], we reported that the shape of $\mathrm{TiO}_{2}$ nanotube arrays prepared by anodization were likely to be a corn shape type and that the thicker bottom layer disturbed the electron transport and electrolyte diffusion. Therefore, we suggested that the removal of the bottom layer would facilitate better energy conversion efficiency in DSSCs. Figure $2 \mathrm{~d}$ shows the side view of freestanding $\mathrm{TiO}_{2}$ nanotube arrays and large $\mathrm{TiO}_{2}$ NPs on the FTO glass. The thickness of the freestanding $\mathrm{TiO}_{2}$ nanotube arrays was approximately $18 \mu \mathrm{m}$, and the thickness of large $\mathrm{TiO}_{2} \mathrm{NPs}$ was approximately $3 \mu \mathrm{m}$.
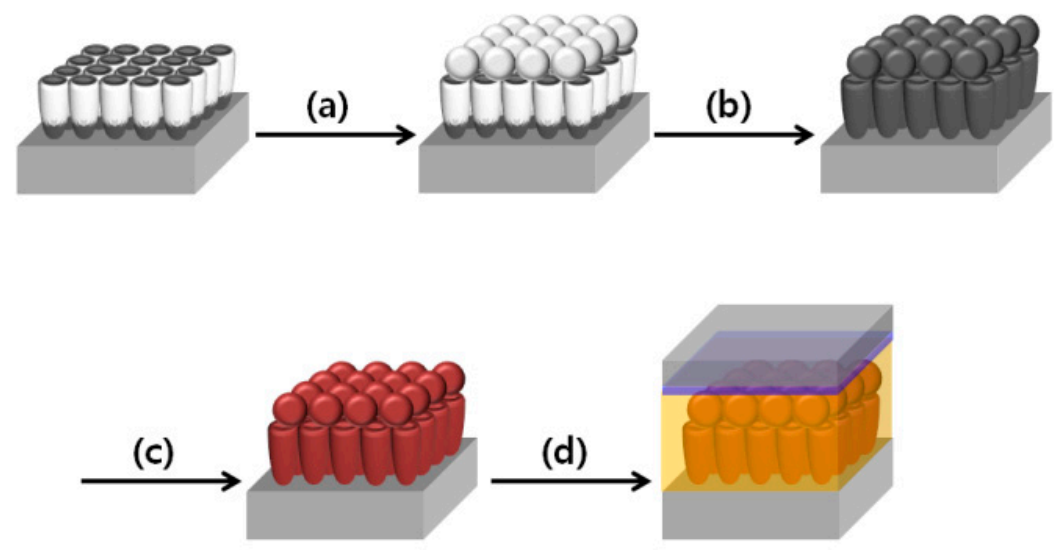

Figure 1. Overall scheme of fabrication of dye-sensitized solar cells (DSSCs) based on closed- or open-ended freestanding $\mathrm{TiO}_{2}$ nanotube arrays decorated with large $\mathrm{TiO}_{2}$ nanoparticles (NPs) and carbon materials. (a) Coating of large $\mathrm{TiO}_{2} \mathrm{NPs}$; (b) Synthesis of carbon materials by chemical vapor deposition (CVD) method; (c) Dye adsorption; and (d) Fabrication of the DSSCs.
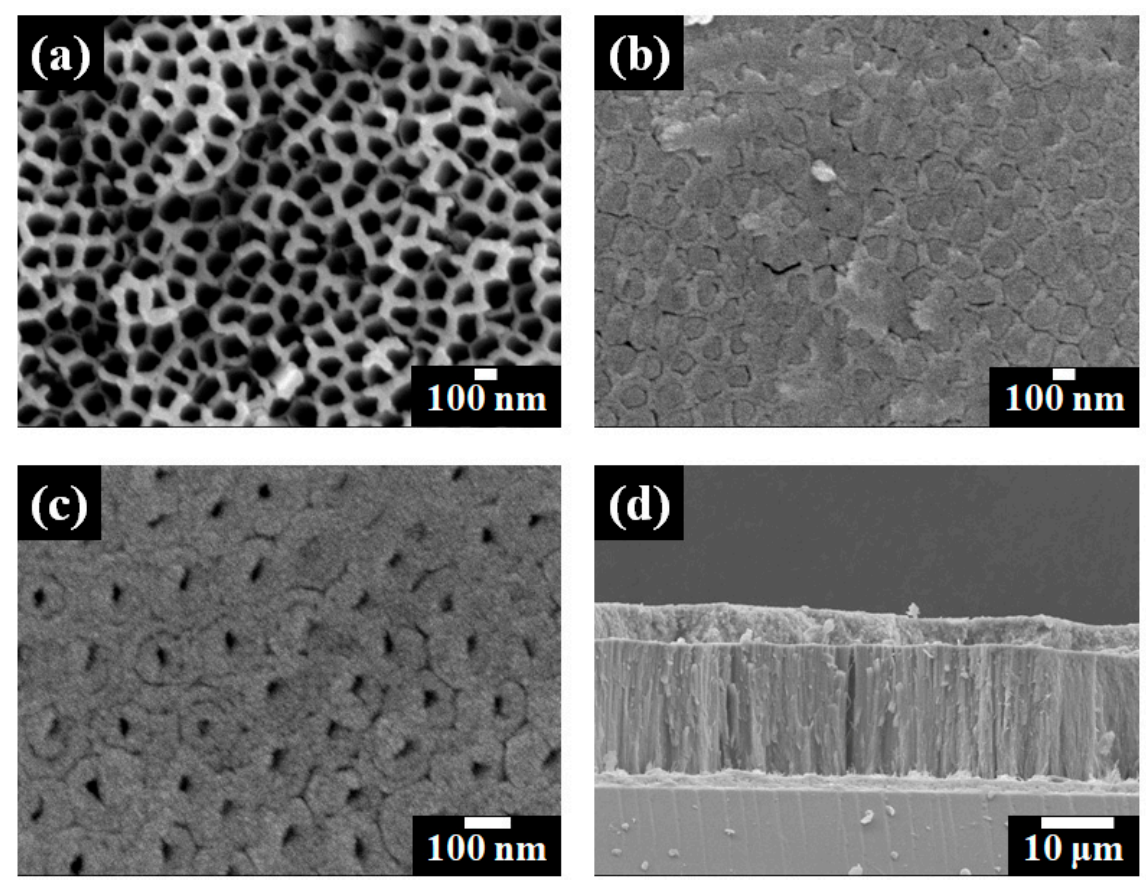

Figure 2. Field emission scanning electron microscope (FE-SEM) images of freestanding $\mathrm{TiO}_{2}$ nanotube arrays. (a) Top view; (b) Bottom view before ion milling process; (c) Bottom view after ion milling process of freestanding $\mathrm{TiO}_{2}$ nanotube arrays; and (d) Side view of freestanding $\mathrm{TiO}_{2}$ nanotube arrays and large $\mathrm{TiO}_{2}$ NPs on the fluorine-doped tin oxide (FTO) glass. 
Carbon materials were synthesized on the freestanding $\mathrm{TiO}_{2}$ nanotube arrays by the CVD method, and their structure was confirmed by Raman spectroscopy, as shown in Figure 3 . The $\mathrm{TiO}_{2}$ nanotube arrays were confirmed at B1g $\left(395 \mathrm{~cm}^{-1}\right), \operatorname{A1g}\left(517 \mathrm{~cm}^{-1}\right)$, and $\mathrm{Eg}\left(639 \mathrm{~cm}^{-1}\right)$ peaks, indicating that the form of the $\mathrm{TiO}_{2}$ nanotube arrays was anatase (Figure 3a). Previously, we have attempted to confirm carbon materials using a transmission electron microscopy (TEM), but experienced difficulties in distinguishing the carbon materials that were located on the wall of $\mathrm{TiO}_{2}$ nanotube arrays [30,31]. Using Raman spectroscopy, on the other hand, the carbon materials on the freestanding $\mathrm{TiO}_{2}$ nanotube arrays could be confirmed from the $G$ band at $1600 \mathrm{~cm}^{-1}$, representing graphite, and the $\mathrm{D}$ band at $1384 \mathrm{~cm}^{-1}$, representing a disorderly network of $\mathrm{sp}^{2}$ and $\mathrm{sp}^{3}$ sites in the carbon materials (Figure $3 \mathrm{~b}$ ). In the $\mathrm{sp}^{2}$ sites of carbon materials, $\pi-\pi$ conjugation had a positive effect on electron transport in enhancing the energy conversion efficiency of DSSCs.
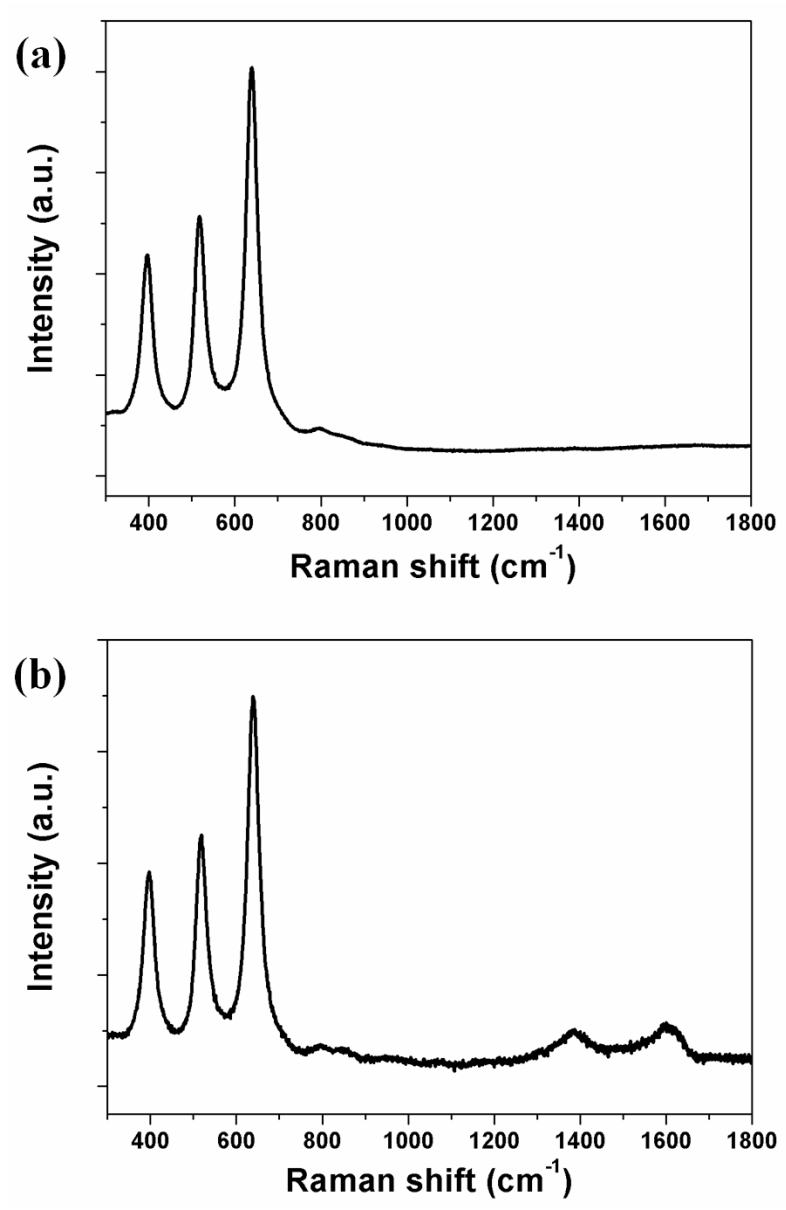

Figure 3. Raman spectra of (a) freestanding $\mathrm{TiO}_{2}$ nanotube arrays alone and (b) freestanding $\mathrm{TiO}_{2}$ nanotube arrays with carbon materials.

The current density-voltage curves $(I-V)$ of DSSCs based on closed-ended $\mathrm{TiO}_{2}$ nanotube

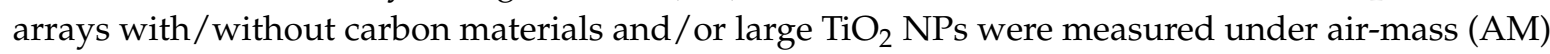
1.5 sunlight. The results are presented in Figure 4 . The open circuit voltage $\left(V_{\mathrm{oc}}\right)$, short-circuit current density $\left(J_{\mathrm{sc}}\right)$, fill factor $(f f)$, and energy conversion efficiency $(\eta)$ of DSSCs are summarized in Table 1. In DSSCs based on closed-ended $\mathrm{TiO}_{2}$ nanotube arrays without carbon materials and large $\mathrm{TiO}_{2} \mathrm{NPs}_{\text {, }}$ the energy conversion efficiency was $4.47 \%$. In DSSCs based on closed-ended $\mathrm{TiO}_{2}$ nanotube arrays with carbon materials or with large $\mathrm{TiO}_{2}$ NPs, the energy conversion efficiency values were $5.24 \%$ and $5.63 \%$, respectively. Although DSSCs based on closed-ended $\mathrm{TiO}_{2}$ nanotube arrays with carbon materials had lower dye loading (from $138 \mathrm{nmol} / \mathrm{cm}^{2}$ to $124 \mathrm{nmol} / \mathrm{cm}^{2}$ ), as dye could not be adsorbed 
onto the carbon materials, the energy conversion efficiency values were higher than that of DSSCs without carbon materials and large $\mathrm{TiO}_{2}$ NPs. Nevertheless, electron transport would be improved by carbon materials, which can enhance the energy conversion efficiency of DSSCs. In DSSCs with large $\mathrm{TiO}_{2}$ NPs, their energy conversion efficiency was higher than that of DSSCs without carbon materials and large $\mathrm{TiO}_{2}$ NPs. In this case, their light harvesting would also be improved by large $\mathrm{TiO}_{2} \mathrm{NPs}_{\text {, }}$ which are favorable in enhancing the energy conversion efficiency. Additionally, the DSSCs based on closed-ended $\mathrm{TiO}_{2}$ nanotube arrays with carbon materials and large $\mathrm{TiO}_{2} \mathrm{NPs}$ showed increased energy conversion efficiency from $4.47 \%$ to $6.52 \%$, corresponding to a $45.86 \%$ enhancement. The results can be attributed to their improved electron transport and light harvesting by $\pi-\pi$ conjugation and scattering layer. These results suggest that the increase in energy conversion efficiency of DSSCs depends on the improved ability of electron transport and light harvesting by carbon materials and large $\mathrm{TiO}_{2}$ NPs.

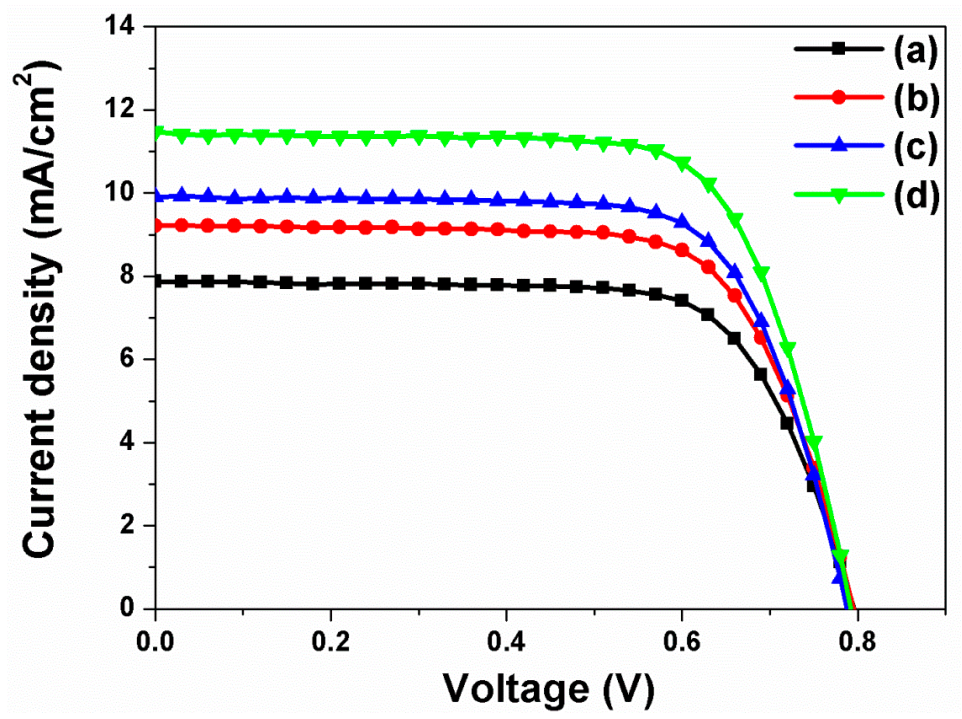

Figure 4. Current density-voltage $(I-V)$ curves of DSSCs based on closed-ended freestanding $\mathrm{TiO}_{2}$ nanotube arrays: (a) Without carbon materials and large $\mathrm{TiO}_{2} \mathrm{NPs}$; (b) With carbon materials; (c) With large $\mathrm{TiO}_{2} \mathrm{NPs}$; and (d) With carbon materials and large $\mathrm{TiO}_{2} \mathrm{NPs}$.

Table 1. Photovoltaic properties of DSSCs based on closed-ended freestanding $\mathrm{TiO}_{2}$ nanotube arrays with/without carbon materials and with/without large $\mathrm{TiO}_{2} \mathrm{NPs}$.

\begin{tabular}{cccccc}
\hline $\begin{array}{c}\text { Based on Closed-Ended Freestanding } \mathrm{TiO}_{\mathbf{2}} \\
\text { Nanotube Arrays }\end{array}$ & $\begin{array}{c}\boldsymbol{J}_{\mathbf{s c}} \\
\left(\mathbf{m A} / \mathbf{c m}^{\mathbf{2}}\right)\end{array}$ & $\begin{array}{c}\boldsymbol{V}_{\mathbf{o c}} \\
\mathbf{( V )}\end{array}$ & ff & $\begin{array}{c}\eta \\
(\mathbf{\%})\end{array}$ & $\begin{array}{c}\text { Dye Loading } \\
\left(\mathbf{n m o l} / \mathbf{c m}^{\mathbf{2}} \mathbf{)}\right.\end{array}$ \\
\hline Without carbon materials and large $\mathrm{TiO}_{2} \mathrm{NPs}$ & 7.87 & 0.80 & 0.71 & 4.47 & 138 \\
\hline With carbon materials & 9.22 & 0.80 & 0.71 & 5.24 & 124 \\
\hline With large $\mathrm{TiO}_{2} \mathrm{NPs}$ & 9.90 & 0.79 & 0.72 & 5.63 & 149 \\
\hline With carbon materials and large $\mathrm{TiO}_{2} \mathrm{NPs}$ & 11.47 & 0.79 & 0.72 & 6.52 & 131 \\
\hline Note: $J_{\text {sc }}$ : short-circuit current density; $V_{\text {oc }}$ : open circuit voltage; ff: fill factor; $\eta$ : energy conversion efficiency.
\end{tabular}

The current density-voltage curves of DSSCs based on open-ended $\mathrm{TiO}_{2}$ nanotube arrays with/without carbon materials were also measured under AM 1.5 sunlight, and the results are presented in Figure 5. The values of $V_{\mathrm{oc}}, J_{\mathrm{sc}}, f f$, and $\eta$ of DSSCs are summarized in Table 2. In general, the energy conversion efficiencies of DSSCs based on the open-ended $\mathrm{TiO}_{2}$ nanotube arrays were higher than those based on the closed-ended $\mathrm{TiO}_{2}$ nanotube arrays. Our previous work demonstrated that the electron transfer and electrolyte diffusion of DSSCs based on open-ended $\mathrm{TiO}_{2}$ nanotube arrays were 
better than that based on closed-ended $\mathrm{TiO}_{2}$ nanotube arrays [18]. The energy conversion efficiency of DSSCs based on open-ended $\mathrm{TiO}_{2}$ nanotube arrays increased from $4.47 \%$ to $5.39 \%$. When the carbon materials were decorated on the $\mathrm{TiO}_{2}$ nanotube arrays, the energy conversion efficiency of DSSCs based on the open-ended $\mathrm{TiO}_{2}$ nanotube arrays increased from $5.39 \%$ to $6.19 \%$ (14.84\% enhancement), which is due to better electron transport by $\pi-\pi$ conjugation. When the large $\mathrm{TiO}_{2} \mathrm{NPs}$ were introduced onto the open-ended $\mathrm{TiO}_{2}$ nanotube arrays, the energy conversion efficiency of DSSCs increased from $5.39 \%$ to $6.24 \%$ (15.77\% enhancement), due to more light harvesting by the scattering layer. To capitalize on the synergetic effects between carbon materials and large $\mathrm{TiO}_{2} \mathrm{NPs}$ in improving energy conversion efficiency, the DSSCs based on open-ended $\mathrm{TiO}_{2}$ nanotube arrays were fabricated with carbon materials and large $\mathrm{TiO}_{2}$ NPs. The energy conversion efficiency increased from $5.39 \%$ to $6.98 \%(29.50 \%$ enhancement). It can be suggested that greater electron transport was facilitated by carbon materials and the better light harvesting by large $\mathrm{TiO}_{2} \mathrm{NPs}$, both of which simultaneously improved the energy conversion efficiency of DSSCs. Moreover, the results showed that the energy conversion efficiencies of DSSCs based on open-ended $\mathrm{TiO}_{2}$ nanotube arrays were mostly greater than those based on closed-ended $\mathrm{TiO}_{2}$ nanotube arrays.

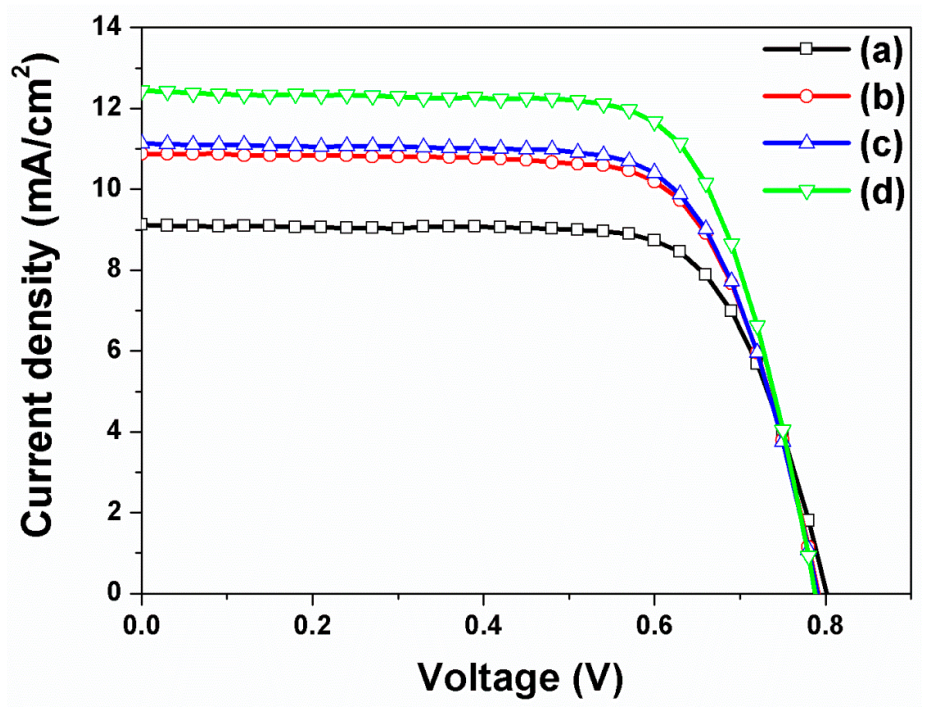

Figure 5. $I-V$ curves of DSSCs based on open-ended freestanding $\mathrm{TiO}_{2}$ nanotube arrays: (a) Without carbon materials and large $\mathrm{TiO}_{2} \mathrm{NPs}$; (b) With carbon materials; (c) With large $\mathrm{TiO}_{2} \mathrm{NPs}$; and (d) With carbon materials and large $\mathrm{TiO}_{2} \mathrm{NPs}$.

Table 2. Photovoltaic properties of DSSCs based on open-ended freestanding $\mathrm{TiO}_{2}$ nanotube arrays with/without carbon materials and with/without large $\mathrm{TiO}_{2} \mathrm{NPs}$

\begin{tabular}{|c|c|c|c|c|c|}
\hline $\begin{array}{c}\text { Based on Open-Ended Freestanding } \mathrm{TiO}_{2} \\
\text { Nanotube Arrays }\end{array}$ & $\begin{array}{c}J_{\mathrm{sc}} \\
\left(\mathrm{mA} / \mathrm{cm}^{2}\right)\end{array}$ & $\begin{array}{l}V_{\text {oc }} \\
\text { (V) }\end{array}$ & $f f$ & $\begin{array}{c}\eta \\
(\%)\end{array}$ & $\begin{array}{l}\text { Dye Loading } \\
\left(\mathrm{nmol} / \mathrm{cm}^{2}\right)\end{array}$ \\
\hline Without carbon materials and large $\mathrm{TiO}_{2} \mathrm{NPs}$ & 9.12 & 0.81 & 0.73 & 5.39 & 150 \\
\hline With carbon materials & 10.88 & 0.79 & 0.72 & 6.19 & 136 \\
\hline With large $\mathrm{TiO}_{2} \mathrm{NPs}$ & 11.14 & 0.79 & 0.71 & 6.24 & 158 \\
\hline With carbon materials and large $\mathrm{TiO}_{2} \mathrm{NPs}$ & 12.44 & 0.79 & 0.71 & 6.98 & 141 \\
\hline
\end{tabular}

Note: $J_{\mathrm{sc}}$ : short-circuit current density; $V_{\mathrm{oc}}$ : open circuit voltage; $f f$ : fill factor; $\eta$ : energy conversion efficiency.

The DSSCs based on the open-ended $\mathrm{TiO}_{2}$ nanotube array were characterized by electrical impedance spectroscopy (EIS) across the frequency range from $10^{-2} \mathrm{~Hz}$ to $10^{6} \mathrm{~Hz}$ (as shown in Figure 6), and the fit parameters are listed in Table 3. The applied bias voltage was set at the $V_{o c}$ with an AC amplitude of $10 \mathrm{mV}$. The ohmic series resistance $\left(R_{S}\right)$ is a sheet resistance corresponding to the $x$-axis value where a first semicircle begins, as can been seen on the left of Figure 6 . When the $R_{s}$ 
value in DSSCs based on the open-ended $\mathrm{TiO}_{2}$ nanotube arrays is compared, it was similar to that with/without carbon materials and/or large $\mathrm{TiO}_{2} \mathrm{NPs}$. The result indicates that the resistance of the sheet against the FTO or the current collector is not affected by the carbon materials and large $\mathrm{TiO}_{2}$ NPs. The $R_{1}$ value is the sum of the small semicircles at the high frequency. The value was assigned to the parallel combination of resistances and the capacitances at the Pt-FTO/electrolyte and the FTO/ $\mathrm{TiO}_{2}$ interfaces. The $R_{1}$ value of DSSCs without carbon materials and large $\mathrm{TiO}_{2} \mathrm{NPs}$ was $6.16 \Omega$, and the $R_{1}$ value of DSSCs with carbon materials or large $\mathrm{TiO}_{2}$ NPs was $6.23 \Omega$ and

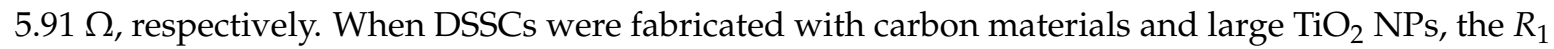
value became $5.11 \Omega$, which was much lower than without carbon materials and large $\mathrm{TiO}_{2} \mathrm{NPs}_{\text {. }}$ The results indicate that a greater amount of electrons were generated by the large $\mathrm{TiO}_{2} \mathrm{NPs}_{\text {, and that }}$ electrons were transferred between the FTO and the $\mathrm{TiO}_{2}$. The $R_{2}$ value is given by the sum of the large semicircles at low frequency, which is also associated with the resistance and the capacitance at the dye-adsorbed $\mathrm{TiO}_{2}$ /electrolyte interface and the transport resistance. The $R_{2}$ value of DSSCs without carbon materials and large $\mathrm{TiO}_{2} \mathrm{NPs}$ was $56.27 \Omega$. When carbon materials were decorated on the $\mathrm{TiO}_{2}$ nanotube arrays, the $R_{2}$ value decreased to $37.43 \Omega$, as transport resistance decreased by $\pi-\pi$ conjugation. The $R_{2}$ value of DSSCs with large $\mathrm{TiO}_{2} \mathrm{NPs}$ decreased to $34.26 \Omega$, due to greater electrons being generated by scattering at the dye-adsorbed $\mathrm{TiO}_{2}$ /electrolyte interface. In DSSCs based on the open-ended $\mathrm{TiO}_{2}$ nanotube arrays with carbon materials and large $\mathrm{TiO}_{2} \mathrm{NPs}$, the value of $R_{2}$ decreased to $29.02 \Omega$ due to the synergistic effect by $\pi-\pi$ conjugation and by scattering layer, affecting the $\mathrm{FTO} / \mathrm{TiO}_{2}$ and $\mathrm{TiO}_{2}$ / electrolyte interfaces.

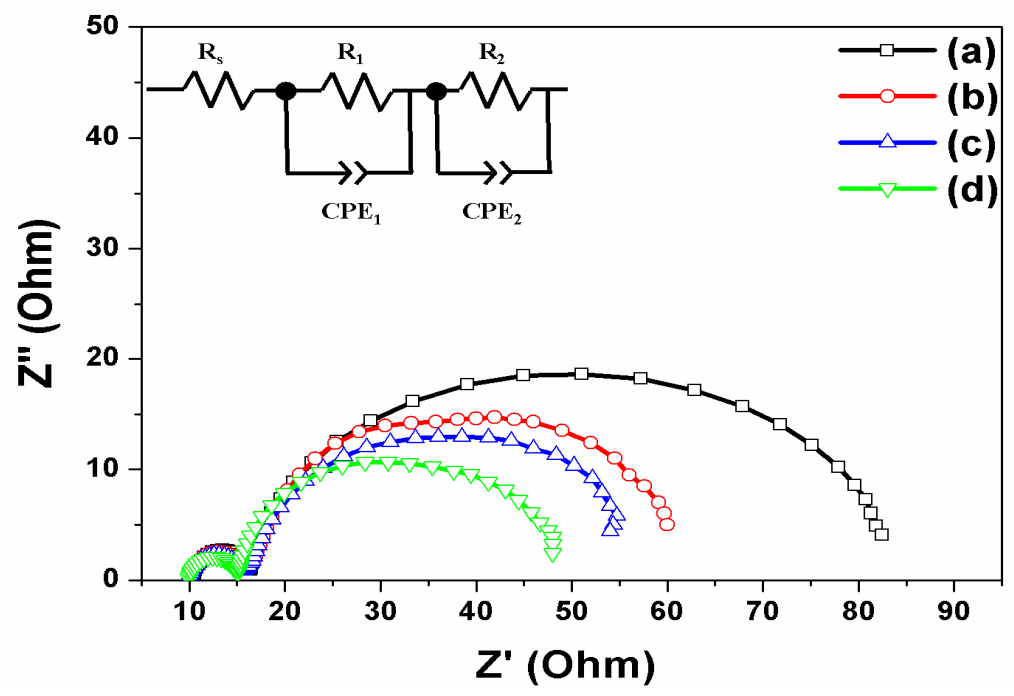

Figure 6. Impedance of DSSCs based on open-ended freestanding $\mathrm{TiO}_{2}$ nanotube arrays: (a) Without carbon materials and large $\mathrm{TiO}_{2} \mathrm{NPs}$; (b) With carbon materials; (c) With large $\mathrm{TiO}_{2} \mathrm{NPs}$; and (d) With carbon materials and large $\mathrm{TiO}_{2}$ NPs.

Table 3. Parameters of impedance spectra of DSSCs based on open-ended freestanding $\mathrm{TiO}_{2}$ nanotube arrays with/without carbon materials and with/without large $\mathrm{TiO}_{2} \mathrm{NPs}$.

\begin{tabular}{cccccc}
\hline $\begin{array}{c}\text { Based on Open-Ended Freestanding } \mathrm{TiO}_{\mathbf{2}} \\
\text { Nanotube Arrays }\end{array}$ & $\begin{array}{c}\boldsymbol{R}_{\mathbf{s}} \\
\mathbf{(} \mathbf{)}\end{array}$ & $\begin{array}{c}\boldsymbol{R}_{\mathbf{1}} \\
\mathbf{(} \mathbf{\Omega})\end{array}$ & $\begin{array}{c}\mathbf{C P E}_{\mathbf{1}} \\
\mathbf{( F )}\end{array}$ & $\begin{array}{c}\boldsymbol{R}_{\mathbf{2}} \\
(\boldsymbol{\Omega})\end{array}$ & $\begin{array}{c}\boldsymbol{C P E}_{\mathbf{2}} \\
\mathbf{( F )}\end{array}$ \\
\hline Without carbon materials and large $\mathrm{TiO}_{2} \mathrm{NPs}$ & 10.67 & 6.16 & $7.59 \times 10^{-6}$ & 56.27 & $1.99 \times 10^{-3}$ \\
With carbon materials & 10.43 & 6.23 & $8.89 \times 10^{-6}$ & 37.43 & $1.94 \times 10^{-3}$ \\
With large $\mathrm{TiO}_{2} \mathrm{NPs}^{-6}$ & 10.40 & 5.91 & $7.91 \times 10^{-6}$ & 34.26 & $2.21 \times 10^{-3}$ \\
With carbon materials and large $\mathrm{TiO}_{2} \mathrm{NPs}$ & 10.26 & 5.11 & $9.86 \times 10^{-6}$ & 29.02 & $2.51 \times 10^{-3}$ \\
\hline
\end{tabular}

Note: $R_{\mathrm{S}}$ : ohmic series resistance; $R_{1}$ : sum of small semicircles at high frequency; $C P E_{1}$ : constant phase element 1 ; $R_{2}$ : sum of large semicircles at low frequency; $C P E_{2}$ : constant phase element 2 . 


\section{Materials and Methods}

\subsection{Materials}

Titanium (Ti) plate (99.7\% purity, $0.25 \mathrm{~mm}$ thickness), ammonium fluoride $\left(\mathrm{NH}_{4} \mathrm{~F}, 97.0 \%\right)$, ethylene glycol (99\%), hydrogen peroxide (30\%), FTO glass, titanium diisopropoxide bis(acetylacetonate) solution (75 wt. \% in isopropanol), $n$-butanol, $\mathrm{TiO}_{2}$ paste, scattering $\mathrm{TiO}_{2}$ paste, titanium chloride $\left(\mathrm{TiCl}_{4}\right)$, dye cis-diisothiocyanato-bis(2,2'-bipyridyl-4,4'-dicarboxylato) ruthenium(II) bis(tetrabutylammonium), N719, chloroplatinic acid hexahydrate $\left(\mathrm{H}_{2} \mathrm{PtCl}_{6} \cdot 6 \mathrm{H}_{2} \mathrm{O}\right)$, 1-butyl-3-methyl-imidazolium iodide (BMII), iodine $\left(\mathrm{I}_{2}\right)$, guanidium thiocyanate $(\mathrm{GSCN})$, 4-tertbutylpyridine $(\mathrm{TBP})$, acetonitrile $\left(\mathrm{CH}_{3} \mathrm{CN}\right)$, and valeronitrile $\left(\mathrm{CH}_{3}\left(\mathrm{CH}_{2}\right)_{3} \mathrm{CN}\right)$ were purchased from Alfa Aesar (Haverhill, MA, USA), Showa Chemical Co., (Beijing, China), Daejung Chemical (Shiheung-City, Korea), Pilkington (St. Helens, UK), Aldrich (St. Louis, MO, USA), Solaronix (Aubonne, Switzerland), and Dyesol (Queanbeyan, Australia).

\subsection{Preparation of Closed- or Open-Ended Freestanding $\mathrm{TiO}_{2}$ Nanotube Arrays}

$\mathrm{TiO}_{2}$ nanotube arrays were prepared by anodization from a $\mathrm{Ti}$ plate that was carried out in an electrolyte composed of $0.8 \mathrm{wt} . \% \mathrm{NH}_{4} \mathrm{~F}$ and 2 vol. $\% \mathrm{H}_{2} \mathrm{O}$ in ethylene glycol. The constant voltage was $60 \mathrm{~V} \mathrm{DC}$ at $25^{\circ} \mathrm{C}$ for $2 \mathrm{~h}$. After the anodization, the Ti plate was annealed at $500{ }^{\circ} \mathrm{C}$ for 30 min under ambient conditions to improve the crystallinity of $\mathrm{TiO}_{2}$ nanotube arrays. To detach the $\mathrm{TiO}_{2}$ nanotube arrays from the Ti plate, a secondary anodization was carried out at a constant voltage of $30 \mathrm{~V}$ DC for $10 \mathrm{~min}$ and then the Ti plate was immersed in $10 \% \mathrm{H}_{2} \mathrm{O}_{2}$ solution for several hours, the results of which are called closed-ended freestanding $\mathrm{TiO}_{2}$ nanotube arrays. To prepare open-ended freestanding $\mathrm{TiO}_{2}$ nanotube arrays, the bottom of the freestanding $\mathrm{TiO}_{2}$ nanotube arrays was removed by ion milling with $\mathrm{Ar}^{+}$bombardment for several minutes.

\subsection{Fabrication of DSSCs with Closed- or Open-Ended Freestanding $\mathrm{TiO}_{2}$ Nanotube Arrays with Scattering Layer}

The $\mathrm{TiO}_{2}$ paste was coated on the FTO glass, and the closed- or open-ended freestanding $\mathrm{TiO}_{2}$ nanotube arrays were put on the substrates and then sintered at $500{ }^{\circ} \mathrm{C}$ for $1 \mathrm{~h}$ under ambient conditions to induce crystallinity and adhesion between the $\mathrm{TiO}_{2} \mathrm{NPs}$ and freestanding $\mathrm{TiO}_{2}$ nanotube arrays. After an annealing step, the $\sim 400 \mathrm{~nm} \mathrm{TiO} 2$ NPs were coated on the freestanding $\mathrm{TiO}_{2}$ nanotube arrays for a scattering layer and sintered at $500{ }^{\circ} \mathrm{C}$ for $1 \mathrm{~h}$ under ambient conditions for their crystallinity. To increase the dye adsorption, the substrates were treated with $0.01 \mathrm{M} \mathrm{TiCl}_{4}$ solution for 30 min and sintered at $500{ }^{\circ} \mathrm{C}$ for $1 \mathrm{~h}$ under ambient conditions for their crystallinity. The substrates were immersed in a dye solution at $50{ }^{\circ} \mathrm{C}$ for $8 \mathrm{~h}$, which were then called working electrodes. The working electrodes were sandwiched with a counter electrode that was coated with Pt on the FTO glass by using a 60 - $\mu$ m-thick hot-melt sheet. The electrolyte was filled between the working and the counter electrode. The electrolyte was comprised of $0.7 \mathrm{M}$ 1-butyl-3-methyl-imidazolium iodide (BMII), $0.03 \mathrm{M} \mathrm{I}_{2}, 0.1 \mathrm{M}$ guanidium thiocyanate (GSCN), and 0.5 M 4-tertbutylpyridine (TBP) in a mixture of acetonitrile and valeronitrile $(85: 15, v / v)$.

\subsection{Instruments}

The morphology, thickness, size, and structure of freestanding $\mathrm{TiO}_{2}$ nanotube arrays were confirmed using a FE-SEM (JSM-6330F, JEOL Inc., Tokyo, Japan). The current density-voltage (J-V) characteristics and the incident photon-to-current conversion efficiency (IPCE) of the DSSCs were measured using an electrometer (Keithley 2400, Keithley Instruments, Inc., Cleveland, OH, USA) under AM 1.5 illumination $\left(100 \mathrm{~mW} / \mathrm{cm}^{2}\right)$ provided by a solar simulator (1 KW xenon with AM 1.5 filter) or using a McScience (model K3100, McScience Inc., Suwon, Korea) with reference to a calibrated diode. 


\section{Conclusions}

We prepared DSSCs based on closed- or open-ended $\mathrm{TiO}_{2}$ nanotube arrays as photoanodes that contained the carbon materials and large $\mathrm{TiO}_{2} \mathrm{NPs}$ to improve energy conversion efficiency. The energy conversion efficiency of DSSCs based on the closed- or open-ended $\mathrm{TiO}_{2}$ nanotube arrays with carbon materials had higher energy conversion efficiency than that of DSSCs without carbon materials. This was due to the carbon materials being composed of $\pi-\pi$ conjugation on their structure, which is more conducive to electron transports. The energy conversion efficiency of DSSCs based on the closed- or open-ended $\mathrm{TiO}_{2}$ nanotube arrays with large $\mathrm{TiO}_{2} \mathrm{NPs}$ showed greater energy conversion efficiency than that of DSSCs without large $\mathrm{TiO}_{2} \mathrm{NPs}$, as large $\mathrm{TiO}_{2} \mathrm{NPs}_{\text {c could generate }}$ more electrons by light harvesting. Moreover, the energy conversion efficiency of DSSCs based on the closed- or open-ended $\mathrm{TiO}_{2}$ nanotube arrays with carbon materials and with large $\mathrm{TiO}_{2} \mathrm{NPs}_{\text {showed }}$ much higher energy conversion efficiency than that of DSSCs without carbon materials and large $\mathrm{TiO}_{2}$ NPs due to their combined effects of enhanced electron transports and electron generation. Our results suggest that the carbon materials and large $\mathrm{TiO}_{2}$ NPs could be applied to organic solar cells (e.g., hybrid or perovskite solar cells) to improve their energy conversion efficiency.

Supplementary Materials: The following are available online at http://www.mdpi.com/2079-4991/7/10/345/s1.

Acknowledgments: This work was supported by the Bio \& Medical Technology Development Program of the National Research Foundation (NRF) and funded by the Korean government (MSIP \& MOHW) (2016M3A9B6918892).

Author Contributions: Rho, W.-Y. conceived and designed the experiments; Song, D.H. performed the experiments; Song, D.H. and Lee, S.H. analyzed the data; Jun, B.-H., Song, D.H., and Rho, W.-Y. wrote the paper.

Conflicts of Interest: The authors declare no conflict of interest. The founding sponsors had no role in the design of the study; in the collection, analyses, or interpretation of data; in the writing of the manuscript, and in the decision to publish the results.

\section{References}

1. Bella, F.; Lamberti, A.; Bianco, S.; Tresso, E.; Gerbaldi, C.; Pirri, C.F. Floating Flexible Polymeric Dye-Sensitized Solar-Cell Architecture: The Way of Near-Future Photovoltaics. Adv. Mater. Technol. 2016, 1, 1600002. [CrossRef]

2. Galliano, S.; Bella, F.; Gerbaldi, C.; Falco, M.; Viscardi, G.; Grätzel, M.; Barolo, C. Photoanode/Electrolyte Interface Stability in Aqueous Dye-Sensitized Solar Cells. Energy Technol. 2017, 5, 300-311. [CrossRef]

3. Oregan, B.; Gratzel, M. A Low-Cost, High-Efficiency Solar-Cell Based on Dye-Sensitized Colloidal TiO 2 Films. Nature 1991, 353, 737-740. [CrossRef]

4. Gratzel, M. Photoelectrochemical cells. Nature 2001, 414, 338-344. [CrossRef] [PubMed]

5. Bella, F.; Gerbaldi, C.; Barolo, C.; Grätzel, M. Aqueous dye-sensitized solar cells. Chem. Soc. Rev. 2015, 44, 3431-3473. [CrossRef] [PubMed]

6. Bella, F.; Pugliese, D.; Zolin, L.; Gerbaldi, C. Paper-based quasi-solid dye-sensitized solar cells. Electrochim. Acta 2017, 237, 87-93. [CrossRef]

7. Shanti, R.; Bella, F.; Salim, Y.; Chee, S.; Ramesh, S.; Ramesh, K. Poly (methyl methacrylate-co-butyl acrylate-co-acrylic acid): Physico-chemical characterization and targeted dye sensitized solar cell application. Mater. Des. 2016, 108, 560-569. [CrossRef]

8. Scalia, A.; Bella, F.; Lamberti, A.; Bianco, S.; Gerbaldi, C.; Tresso, E.; Pirri, C.F. A flexible and portable powerpack by solid-state supercapacitor and dye-sensitized solar cell integration. J. Power Sources 2017, 359, 311-321. [CrossRef]

9. Bella, F.; Verna, A.; Gerbaldi, C. Patterning dye-sensitized solar cell photoanodes through a polymeric approach: A perspective. Mater. Sci. Semicond. Process. 2017. [CrossRef]

10. Nazeeruddin, M.K.; Pechy, P.; Renouard, T.; Zakeeruddin, S.M.; Humphry-Baker, R.; Comte, P.; Liska, P.; Cevey, L.; Costa, E.; Shklover, V.; et al. Engineering of efficient panchromatic sensitizers for nanocrystalline $\mathrm{TiO}_{2}$-based solar cells. J. Am. Chem. Soc. 2001, 123, 1613-1624. [CrossRef] [PubMed] 
11. Hara, K.; Sato, T.; Katoh, R.; Furube, A.; Ohga, Y.; Shinpo, A.; Suga, S.; Sayama, K.; Sugihara, H.; Arakawa, H. Molecular design of coumarin dyes for efficient dye-sensitized solar cells. J. Phys. Chem. B 2003, 107, 597-606. [CrossRef]

12. Galoppini, E. Linkers for anchoring sensitizers to semiconductor nanoparticles. Coord. Chem. Rev. 2004, 248, 1283-1297. [CrossRef]

13. Sang, L.; Zhao, Y.; Burda, C. $\mathrm{TiO}_{2}$ nanoparticles as functional building blocks. Chem. Rev. 2014, 114, 9283-9318. [CrossRef] [PubMed]

14. Du, L.; Furube, A.; Yamamoto, K.; Hara, K.; Katoh, R.; Tachiya, M. Plasmon-induced charge separation and recombination dynamics in gold- $\mathrm{TiO}_{2}$ nanoparticle systems: Dependence on $\mathrm{TiO}_{2}$ particle size. J. Phys. Chem. C 2009, 113, 6454-6462. [CrossRef]

15. Mor, G.K.; Varghese, O.K.; Paulose, M.; Shankar, K.; Grimes, C.A. A review on highly ordered, vertically oriented $\mathrm{TiO}_{2}$ nanotube arrays: Fabrication, material properties, and solar energy applications. Sol. Energy Mater. Sol. Cells 2006, 90, 2011-2075. [CrossRef]

16. Shin, Y.; Lee, S. Self-organized regular arrays of anodic $\mathrm{TiO}_{2}$ nanotubes. Nano Lett. 2008, 8, 3171-3173. [CrossRef] [PubMed]

17. Rho, W.-Y.; Jeon, H.; Kim, H.-S.; Chung, W.-J.; Suh, J.S.; Jun, B.-H. Recent Progress in Dye-Sensitized Solar Cells for Improving Efficiency: $\mathrm{TiO}_{2}$ Nanotube Arrays in Active Layer. J. Nanomater. 2015, 2015, 1-17. [CrossRef]

18. Rho, C.; Min, J.-H.; Suh, J.S. Barrier layer effect on the electron transport of the dye-sensitized solar cells based on $\mathrm{TiO}_{2}$ nanotube arrays. J. Phys. Chem. C 2012, 116, 7213-7218. [CrossRef]

19. Katoh, R.; Furube, A.; Yoshihara, T.; Hara, K.; Fujihashi, G.; Takano, S.; Murata, S.; Arakawa, H.; Tachiya, M. Efficiencies of electron injection from excited N3 dye into nanocrystalline semiconductor $\left(\mathrm{ZrO}_{2}, \mathrm{TiO}_{2}, \mathrm{ZnO}\right.$, $\mathrm{Nb}_{2} \mathrm{O}_{5}, \mathrm{SnO}_{2}, \mathrm{In}_{2} \mathrm{O}_{3}$ ) films. J. Phys. Chem. B 2004, 108, 4818-4822. [CrossRef]

20. Pradhan, B.; Batabyal, S.K.; Pal, A.J. Functionalized carbon nanotubes in donor/acceptor-type photovoltaic devices. Appl. Phys. Lett. 2006, 88, 3106. [CrossRef]

21. Zhang, H.; Lv, X.; Li, Y.; Wang, Y.; Li, J. P25-graphene composite as a high performance photocatalyst. ACS Nano 2010, 4, 380-386. [CrossRef] [PubMed]

22. Yadav, S.K.; Madeshwaran, S.R.; Cho, J.W. Synthesis of a hybrid assembly composed of titanium dioxide nanoparticles and thin multi-walled carbon nanotubes using "click chemistry". J. Colloid Interface Sci. 2011, 358, 471-476. [CrossRef] [PubMed]

23. Nath, N.C.D.; Sarker, S.; Ahammad, A.S.; Lee, J.-J. Spatial arrangement of carbon nanotubes in $\mathrm{TiO}_{2}$ photoelectrodes to enhance the efficiency of dye-sensitized solar cells. Phys. Chem. Chem. Phys. 2012, 14, 4333-4338. [CrossRef] [PubMed]

24. Roy-Mayhew, J.D.; Aksay, I.A. Graphene materials and their use in dye-sensitized solar cells. Chem. Rev. 2014, 114, 6323-6348. [CrossRef] [PubMed]

25. Rho, C.; Suh, J.S. Filling $\mathrm{TiO}_{2}$ nanoparticles in the channels of $\mathrm{TiO}_{2}$ nanotube membranes to enhance the efficiency of dye-sensitized solar cells. Chem. Phys. Lett. 2011, 513, 108-111. [CrossRef]

26. Rho, W.-Y.; Chun, M.-H.; Kim, H.-D.; Hahn, Y.-B.; Suh, J.S.; Jun, B.-H. Improved energy conversion efficiency of dye-sensitized solar cells fabricated using open-ended $\mathrm{TiO}_{2}$ nanotube arrays with scattering layer. Bull. Korean Chem. Soc. 2014, 35, 1165-1168. [CrossRef]

27. Rho, W.-Y.; Kim, H.-S.; Lee, S.H.; Jung, S.; Suh, J.S.; Hahn, Y.-B.; Jun, B.-H. Front-illuminated dye-sensitized solar cells with $\mathrm{Ag}$ nanoparticle-functionalized freestanding $\mathrm{TiO}_{2}$ nanotube arrays. Chem. Phys. Lett. 2014, 614, 78-81. [CrossRef]

28. Rho, W.-Y.; Chun, M.-H.; Kim, H.-S.; Kim, H.-M.; Suh, J.S.; Jun, B.-H. Ag Nanoparticle-Functionalized Open-Ended Freestanding $\mathrm{TiO}_{2}$ Nanotube Arrays with a Scattering Layer for Improved Energy Conversion Efficiency in Dye-Sensitized Solar Cells. Nanomaterials 2016, 6, 117. [CrossRef] [PubMed]

29. Rho, W.-Y.; Kim, H.-S.; Chung, W.-J.; Suh, J.S.; Jun, B.-H.; Hahn, Y.-B. Enhancement of power conversion efficiency with $\mathrm{TiO}_{2}$ nanoparticles/nanotubes-silver nanoparticles composites in dye-sensitized solar cells. Appl. Surf. Sci. 2018. [CrossRef] 
30. Rho, W.-Y.; Kim, H.-S.; Kim, H.-M.; Suh, J.S.; Jun, B.-H. Carbon-doped freestanding $\mathrm{TiO}_{2}$ nanotube arrays in dye-sensitized solar cells. New J. Chem. 2017, 41, 285-289. [CrossRef]

31. Kim, H.-S.; Chun, M.-H.; Suh, J.S.; Jun, B.-H.; Rho, W.-Y. Dual Functionalized Freestanding $\mathrm{TiO}_{2} \mathrm{Nanotube}$ Arrays Coated with Ag Nanoparticles and Carbon Materials for Dye-Sensitized Solar Cells. Appl. Sci. 2017, 7, 576. [CrossRef]

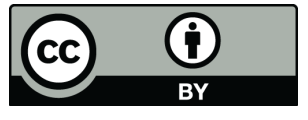

(C) 2017 by the authors. Licensee MDPI, Basel, Switzerland. This article is an open access article distributed under the terms and conditions of the Creative Commons Attribution (CC BY) license (http:/ / creativecommons.org/licenses/by/4.0/). 